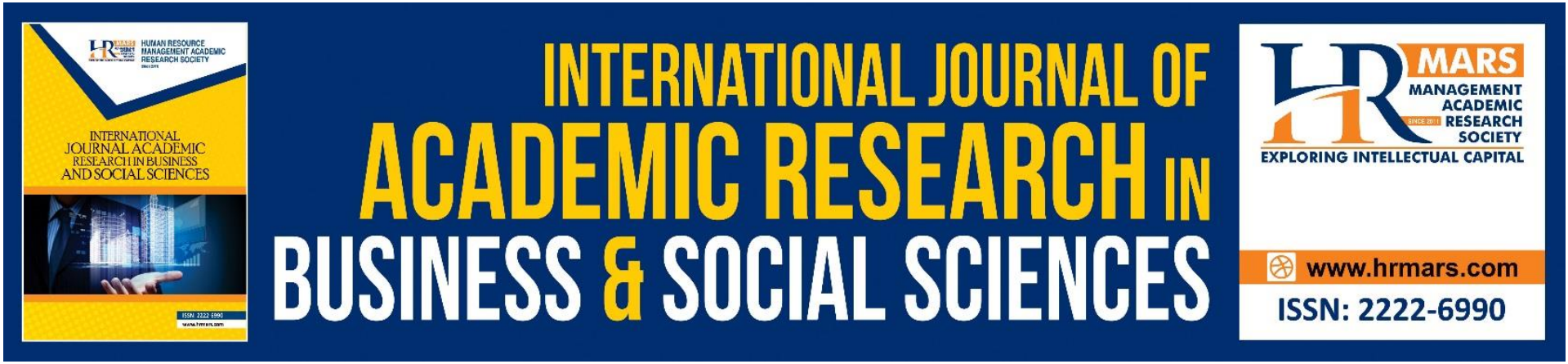

\title{
Mapping the Local Community: Factors Influencing the Purchase Intention of Community based Entrepreneur Halal Products in Malaysia
}

\section{Zuhal Hussein, Amily Fikry}

To Link this Article: http://dx.doi.org/10.6007/IJARBSS/v11-i1/8133

DOI:10.6007/IJARBSS/v11-i1/8133

Received: 10 November 2020, Revised: 01 December 2020, Accepted: 24 December 2020

Published Online: 20 January 2021

In-Text Citation: (Hussein \& Fikry, 2011)

To Cite this Article: Hussein, Z., \& Fikry, A. (2011). Mapping the Local Community: Factors Influencing the Purchase Intention of Community based Entrepreneur Halal Products in Malaysia. International Journal of Academic Research in Business and Social Sciences, 11(1), 296-303.

Copyright: @ 2021 The Author(s)

Published by Human Resource Management Academic Research Society (www.hrmars.com)

This article is published under the Creative Commons Attribution (CC BY 4.0) license. Anyone may reproduce, distribute, translate and create derivative works of this article (for both commercial and non-commercial purposes), subject to full attribution to the original publication and authors. The full terms of this license may be seen at: http://creativecommons.org/licences/by/4.0/legalcode

Vol. 11, No. 1, 2021, Pg. 296 - 303

Full Terms \& Conditions of access and use can be found at http://hrmars.com/index.php/pages/detail/publication-ethics 


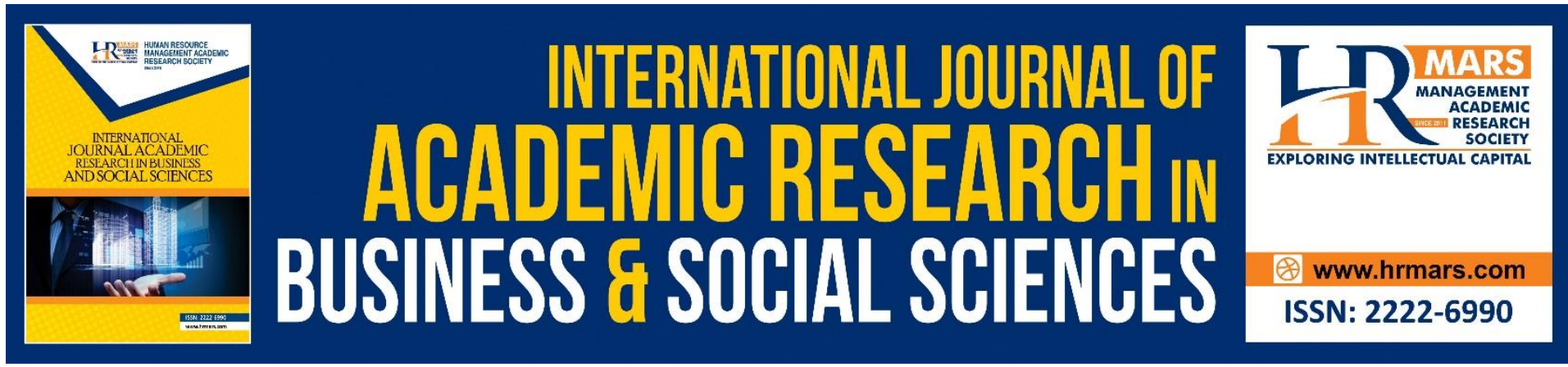

\title{
Mapping the Local Community: Factors Influencing the Purchase Intention of Community based Entrepreneur Halal Products in Malaysia
}

\author{
Zuhal Hussein \\ Associate Professor, Faculty of Business and Management, Universiti Teknologi MARA, \\ Kelantan Branch, Kota Bharu Campus, Lembah Sireh, 15050 Kota Bharu, Kelantan

\section{Amily Fikry} \\ Senior Lecturer, Faculty of Business and Management, Universiti Teknologi MARA, 40450
}

\begin{abstract}
This research is designed to get the analysis of purchase intension of the customer for the local community-based products in Kelantan with focus on the impact of products halal certification and product hygiene on the consumers purchase intention. 100 respondents were recruited in convenient sampling. This quantitative study using survey and questionnaire as a tool of data collection. Results found that the purchasing intention of the Muslims regarding the local community-based halal products is dependent mainly on the halal logo and certification and also the hygienic factor. This study addresses an important knowledge gap in the local community-based product literature, proposing and clarifying the relationship between Halal logo and certification, hygienic factors and purchase intention.
\end{abstract}

Keywords: Halal Product, Halal Certification, Hygienic Factor, Purchase Intention

\section{Introduction}

As per academic literature, community-based entrepreneurship is gaining significant popularity because researches been done in this domain have been increasing (Pierre et al., 2014). Reason behind that the community-based entrepreneurship represents that strategy which could help to foster the local development in the long run. In terms of entrepreneurship, communities are generally been treated as an exogenous part of the environment (e.g. Ardichvila, Cardozo, \& Ray, 2003; Borzaga and Defourny, 2001). The study related to this domain by Dana (2008) suggest that economic goals is one of the expressions of local based entrepreneurship (based on traditional values of mutual support, collective action, social responsibility and environmental stewardship).

To support the local community-based products, consumers need to play their role but other than consumers, buyers need to do their job well too by having enough knowledge about the products like: either they have halal certification or not, how hygienic these products are so hat then can convey this information to the potential and current consumers. This ease for the consumers by the buyers can help in increasing the sales. Consumers do want to buy the local community-based products but the main gap in the market is unawareness of the 
consumers regarding the products which has led to the lack in confidence in buying these types of products even there is will to buy them. The reason behind this lack of information is that the seller or manufacturer has not conveyed the required information. The information been communicated through signs of halal certification on packaging is very important. The absence of such signs can cause doubts in the minds of customers while buying such products. This research is designed to get the analysis of purchase intention of the customer for the local community-based products in East Peninsular Malaysia with focus on the impact of products halal certification and product hygiene on the consumers purchase intention.

The aims of this paper are:

- To identify the factors influencing purchase intention of the customer for the local community-based products

- To examine the relationship between the halal certification and product hygiene on consumers purchase intention

\section{Literature Review}

Several descriptive researches have been done which were specifically focused on the community-based product like as Lotz (1989) discussed the rise of the ventures (such as community development corporations, worker-owned business, and regional development councils) due to crisis in the delivery of service. Torri (2010) a study been conducted on herbal community-based enterprise in India which emphasized on the importance of observing entrepreneurial activity with a more complex and holistic view then been done in the previous years through conventional methods for example entrepreneurial activity, participative approach in the decision-making process, and promoted other social outcomes. Furthermore, a study in Belarus, Ivanova (2004) focused and observed at the entrepreneurial activities in an unfriendly environment. This paper is focused on the purchase intention of communitybased enterprise product considering two variables one is the halal certification and the other one is the hygiene in scope of Malaysia.

\section{Purchase Intention}

Customers do find it difficult to get the products from the market due to the product shortage and besides this problem marketers or retailers are not much familiar about the purchase intension of the consumers of the local community-based products. Purchase intention is defined by Fandos \& Flavian (2006) as an implied commitment to one's self to avail or purchase when the ability to do so arises. This variable is of significant importance for the businessmen because with this variable buying behaviour is positively corelated which means if the customer has the intention to buy there are chances of more sales and vice versa (Morwitz \& Schmittlein, 1992). Hussein (2015), in his study he explained that the common effective measure is the purchase intention which is normally been used to estimate the response behaviour which explains the behaviour tendency of a customer who wants to purchase a product. Therefore, the discernment of purchase intentions is the critical element for the local based-community product to survive in the present hyper competitive environment.

As per the teachings of Islam it is prohibited for the Muslims to consume non-halal food products that is the reason the demand for the halal products in the market is majorly due to the Muslim consumers. But availability of halal products in the markets is not that easy due to their shortage or low supply by the sellers. Eddie, Rezai, Nasir, and Zainal (2009) in their study they analysed the human buying behaviour and suggested that the halal-labelled 
products have impact on the buying process of the customers because of the influence of the signs of halal certificate. Muslims select and buy the food items by identifying halal logo and certification at the food packaging or the premises. In Malaysia, to capture the bigger market of $60.4 \%$ of Muslims, halal logo on packaging attracts a lot of purchases. (Ardyanti et.al, 2013). Several researches have addressed the causal mechanisms of purchase intentions and to survive in this hyper competitive environment it is importance for community-based product to continuously understand the importance of logo of halal certification and its presentation.

\section{Halal Logo and Certification}

For steady, growth it is important for community-based product to establish strong base into halal food and drinks market. Naqiuddin and Raufu (2012) in their paper propose that halal products or foods are now of great importance in the worldwide discussion and one of the reasons is that the halal food is safe, is of good quality and more hygienic. There are certain requirements which needed to be met to make food the halal one as per Islamic Law and those do not just bring the safe food but also social justice, animals' welfare and sustainable environment. Because of the Islamic obligation to eat halal food, the availability of local base food product in the market is the need of the Muslim customers. The logo which declares that the food is halal gains the trusts of the people especially of Muslims who can consume the food without any doubt (Tumin, 2004). It symbolizes religious compliance and quality (AI Harran and Low, 2008). The Halal logo and certification is a significant way to reassure their target consumers that their products are Halal and Shariah compliant, specifically to the Muslim consumers (Shafie et al., 2006).

The food choices by the Muslims been made by identifying halal logo and certification at the food packaging or premises. The major customers of halal food are the Muslims and they are also the majority population of Malaysia. Majid, Abidin, Majid, Chik (2015) keeping Scope to Malaysis, review the issues and challenges of halal food implementation and identified "the problem from the food manufacturers side include inadequate understanding of halal procedures, incomplete documents, defrayment of certification fee in abeyance and incognizant of information to be submitted. While the internal problems identified are lack of expertise because new staffs have little knowledge which slows the halal certification process, unsystematic filing system, premise inspection which required more than a day and delay in receiving lab test result. Being the less tapped market, the enforcement is not that strong as compared to the other food laws and there is no such comprehensive halal act that rise under halal governance".

Moreover, a research by Ardyanti, Nashril, \&Helmi (2013), identified another behaviour that is that the Muslim customer more likely choose food outlet based on taste and price instead of halal certification and logo. It means $m$ that price and taste are the factors of their priority rather than the halal food. Based $\backslash 11$ on above issues it is vital for this study to research the concept of halal on the community-based product in Malaysia on purchase intention.

\section{Hygiene Factor}

Halal certification is not the only determinant for Muslims to purchase halal food. Research by Bonne and Verbeke (2006) show that in Belgium, Muslims customer instead of buying food with halal certification buy the non-halal food which claims through information on packaging that the due care been given to hygiene of the food. This information is not been provided by the Islamic butcher which is the main reason for the Muslims reluctantly to buy that halal meat. Further, another study by Mohamed, Rezai, Shamsudin and Chiew (2008) that the 
purchase behaviour is also dependent on the list of the ingredients although the product has been Halal certified. The consideration of food hygiene is also due to the consumer lifestyle and their concern on the food hygiene and food safety. For Muslim customers, food safety and food hygiene are also important to be considered in making decision to purchase. Food hygiene, safety, and food quality are among the determinants that will be looked before consumers make their purchasing decision (Ardyanti et.al, 2013).Therefore, this study will also adopt hygiene factor as a factor to customers purchase intention.

\section{Method}

This quantitative study recruited 100 respondents who are Muslims from various socio economic background in Kelantan. Kelantan was selected due to the religious commitment of Muslim population in the state. Convenience sampling was used to select the sample size. They were selected randomly to answer the survey. The questionnaires were distributed to them and took around 20 minutes to complete. The consent was obtained from the respondents before starting the survey to ensure the ethical conduct was taken into consideration. The questionnaire consist of four sections include profiling, halal logo and certification, hygiene and purchase intention. Data collected was analysed using SPSS version 20 focusing on Pearson correlation and regression analysis.

\section{Results}

\section{Socio Demographic Information}

\begin{tabular}{|c|c|c|c|}
\hline $\begin{array}{l}\text { Demographic / } \\
\text { Social Variables }\end{array}$ & Categories & $\begin{array}{l}\text { Frequenc } \\
y \\
\mathrm{~N}=100\end{array}$ & (\%) \\
\hline \multirow[t]{2}{*}{ Sex } & Male & 28 & 28 \\
\hline & Female & 72 & 72 \\
\hline \multirow[t]{5}{*}{ Age (Years) } & $18-20$ & 2 & 2 \\
\hline & $21-30$ & 25 & 25 \\
\hline & $31-40$ & 60 & 60 \\
\hline & $41-50$ & 8 & 8 \\
\hline & $51-60$ & 5 & 5 \\
\hline \multirow[t]{3}{*}{ Level of education } & Primary & 1 & 1 \\
\hline & Secondary & 75 & 75 \\
\hline & Tertiary & 24 & 24 \\
\hline \multirow[t]{2}{*}{ Marital status } & Single & 22 & 22 \\
\hline & Married & 78 & 78 \\
\hline Level of income & $<2000$ & 30 & 30 \\
\hline \multirow[t]{3}{*}{ (RM) } & $2001-3000$ & 32 & 32 \\
\hline & $3001-5000$ & 28 & 28 \\
\hline & $>5000$ & 10 & 10 \\
\hline
\end{tabular}

Out of 100 samples, 28 are male respondents (28\%) and 72 are female respondents (72\%).The group of age which has highest percentage is $31-40$ years old which is $60 \%$ and the second highest is between $21-30$ years old which is $25 \%$. The following group is between $41-50$ years old which is $8 \%$ and the lowest percentage is $2 \%$ for the age group of $18-20$ years old. In terms of the level of education, majority of the respondents having secondary education which is 
$75 \%$, followed by tertiary education which is $24 \%$ and only one respondent is having primary education (1\%). Majority of the respondents are married (78\%) and $22 \%$ are single. For the income level, most of the respondents are having the income between RM2001-RM3000 (32\%), followed by income level of less than RM2000 which is $30 \%$. The lowest number of respondents fell into the group of more than RM5000 income level (10\%).

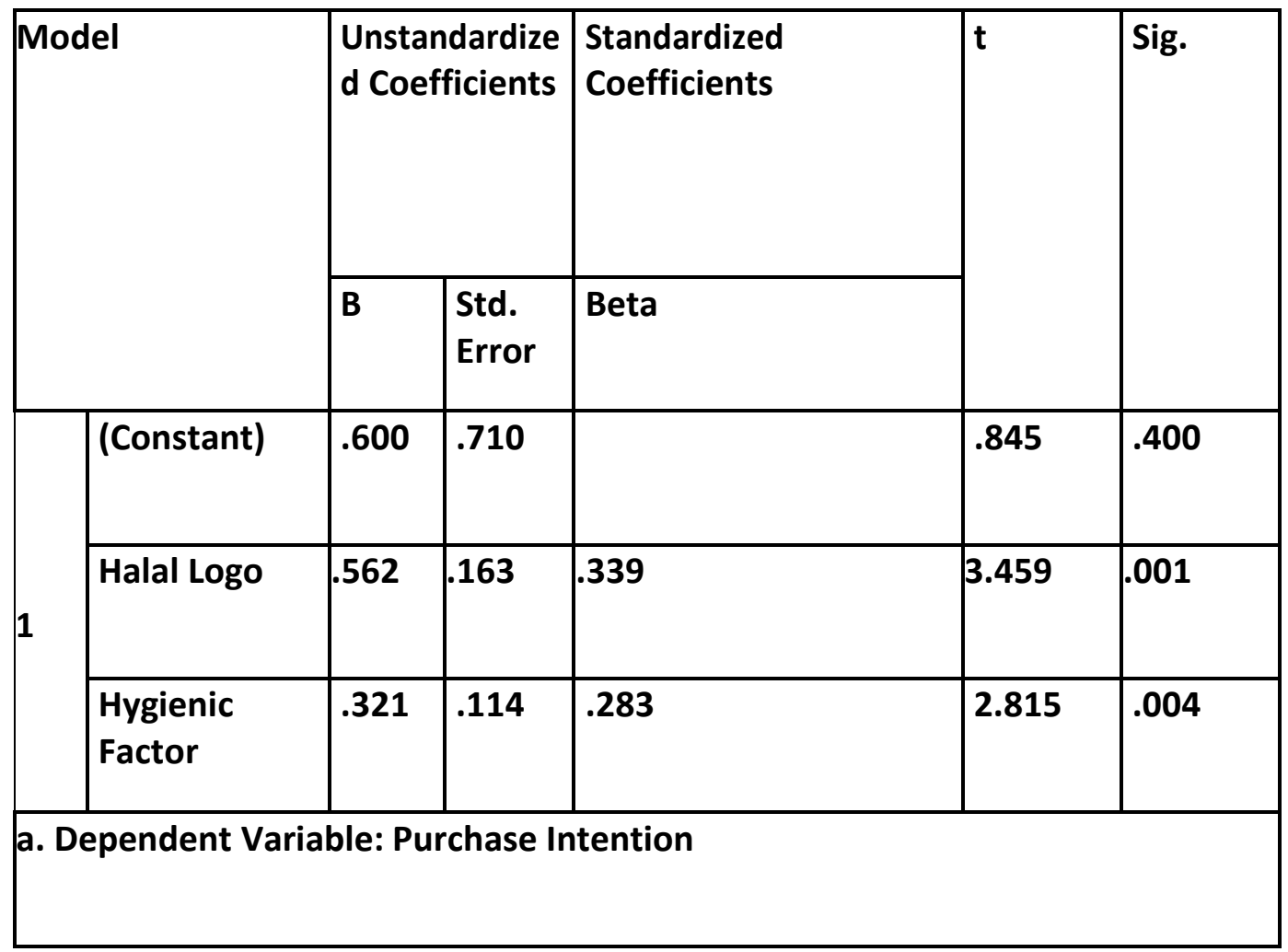

According to the result above, halal logo and hygienic are significant with consumer purchase intention by having a $p$-value $=0.001$ and .004 respectively. The result also found that hall logo is the most important factor that contributes to consumer intention with the highest value of $\beta=0.339$ compared to hygienic factor with $\beta=0.283$. The results indicate that they have a positive relationship between each other. The relationship can be defined by when a factor goes up $1 \%$, and consumer attraction also increases by $\beta \%$ while other variables held constant.

\section{Discussion}

The result of this study shows that the purchasing intention of the Muslims regarding the local community-based products is dependent mainly on the halal logo and certification. This in line with research found by Shaari and Arifin and Golnaz et al. (2010), it has been found that the halal purchase intention can help in understanding the expectations and needs of the customers. In this regard, evaluating the considerable constructs to boost the purchase intention would be another stream that local community-based industry must pay attention to make a superior purchase intention.

A "Halal Certified" stamp on a label is often taken by Muslim customers as a sign of a genuine product or trustworthiness. Malaysia consumers today are aware and have knowledge about Halal food and they are living a more holistic Halal way of life. Malaysian consumers can at any time get information about Halal products and check the originality of Halal logo and 
certification from the websites. It showed that Malaysian have good understanding on the concept of Halal Food and appreciate the concept of Halal product to meet the demands of the religion. Understanding the concept of Halal Food means personal knowledge and belief that associates with Halal food consumption issues. By having such understanding and knowledge, the consumer will have a better picture of what is Halal food consumption. As per the study (Ahmad, 1996), the consumer while buying the local community-based product will be able to make an intelligent decision according to their preferences and faith.

The result of this study shows the importance for local community-based product to reinforce hygiene in their production to influence customers purchase intention. The consideration of food hygiene is due to the consumer lifestyle and their concern on the food hygiene and food safety.

\section{Conclusion}

This paper addresses an important knowledge gap in the local community-based product literature, proposing and clarifying the relationship between Halal logo and certification, Hygiene factors and purchase intention. Therefore for Muslim entrepreneurs of halal food products, they have to educate Muslim consumers by enlighten the advertorial about their halal products so that they are always in concern and have positive perception towards the halal food products in order for the customers to purchase their products. In conclusion, this paper contributes to the additional variables to be added in the theoretical framework of local community based product and these factors are important elements to be considered especially in the Muslims population and culture.

\section{References}

Fandos, C., \& Flavián, C. (2006). Intrinsic and extrinsic quality attributes, loyalty and buying intention: An analysis for a PDO product. British Food Journal, 108(8).

Ardayanti, A., Nashril, T. T. A., \& Helmi, A. (2013). A Study on Halal Food Awareness among Muslims Customers in Klang Valley, 4th International Conference on Business and Economic Research, Bandung, Indonesia, paper 1073. https://www.academia.edu/9229684/A_STUDY_ON_HALAL_FOOD_AWARENESS_AM ONG_MUSLIM_CUSTOMERS_IN_KLANG_VALLEY?auto=download

Morwitz, V. G., \& Schmittlein, D. (1992). Using segmentation to improve sales forecasts based on purchase intent: Which intenders actually buy? Journal of Marketing Research, 391-405.

Lotz, J. (1989). Community entrepreneurs. Community Development Journal, 24(1), 62-66.

Ivanova, Y. V. (2004). Belarus: entrepreneurial activities in an unfriendly environment. Journal of East-West Business, 10(4), 29-54.

Torri, M. C. (2010). Community-based Enterprises: A Promising Basis towards an Alternative Entrepreneurial Model for Sustainability Enhancing Livelihoods and Promoting Socioeconomic Development in Rural India. Journal of Small Business \& Entrepreneurship, 23:2, 237-248, DOI: 10.1080/08276331.2010.10593484

Borzaga, C., and Defourny, J. (2001). The Emergence of Social Enterprise. Routledge: London Hussein, Z. (2015). A Preliminary Study on Halal Certifiable Product: What Really Matters for Muslim Consumers? E-Journal of Academic Minds

Ahuja, G. (2000). The Duality of Collaboration: Inducements and Opportunities in the Formation of Interfirm Linkages. Strategic Management Journal, 21(3): 317-343. 
Community Partnering. (2016). What are community based enterprises? URL: http://www.communitypartnering.info/what45.html.

Peredo, A., Chrisman, J. (2006). Toward a theory of community-based enterprise. Academic Management Review, 31 (2), 309-328.

Pierre, A., Von Friedrichs, Y., Wincent, J. (2014). Entrepreneurship in society: A review and definition of community-based entrepreneurship research. In: Lundström, A., Zhou, C., von Friedrichs, Y., Sundin, E. (Eds.), Social Entrepreneurship: Leveraging Economic, Political, and Cultural Dimensions. International Studies in Entrepreneurship 29. Springer, Heidelberg, Germany, pp. 239-257. 